\title{
Anti-inflammatory effects of essential oils extracted from Chamaecyparis obtusa on murine models of inflammation and RAW 264.7 cells
}

\author{
YUJIN PARK $^{1}$, SEUNG-AH YOO ${ }^{1}$, WAN-UK KIM ${ }^{2}$, CHUL-SOO CHO ${ }^{2}$, \\ JONG-MIN WOO ${ }^{3,4}$ and CHONG-HYEON YOON ${ }^{2}$ \\ ${ }^{1}$ Catholic Research Institutes of Medical Science; ${ }^{2}$ Division of Rheumatology, Department of Internal Medicine, \\ College of Medicine, Catholic University of Korea, Seoul 137-701; ${ }^{3}$ Department of Psychiatry, \\ Seoul Paik Hospital, School of Medicine; ${ }^{4}$ Stress Research Institute, Inje University, \\ Seoul 100-032, Republic of Korea
}

Received February 12, 2015; Accepted January 5, 2016

DOI: $10.3892 / \mathrm{mmr} .2016 .4905$

\begin{abstract}
Antimicrobial, antifungal and anti-inflammatory effects of essential oils extracted from Chamaecyparis obtusa (EOCO) have previously been reported. In the present study, the anti-inflammatory effects of EOCO were investigated in two murine models of inflammation: Carrageenan-induced paw edema and thioglycollate-induced peritonitis, and in lipopolysaccharide (LPS)-stimulated RAW 264.7 macrophage cells. The expression levels of proinflammatory cytokines were analyzed by ELISA, the expression of nitric oxide synthase (iNOS) and cyclooxygenase-2 (COX-2) were determined by western blotting, and nitrite concentration was measured using Griess reagent. In mice with carrageenan-induced edema, paw thickness and the expression levels of interleukin (IL)-1 $\beta$ and IL-6 in paw homogenates were significantly decreased in the EOCO (5 and $10 \mathrm{mg} / \mathrm{kg}$ ) group, as compared with the control group. In mice with thioglycollate-induced peritonitis, treatment with EOCO (5 and $10 \mathrm{mg} / \mathrm{kg}$ ) reduced the number of total cells and suppressed tumor necrosis factor- $\alpha$ (TNF- $\alpha$ ),
\end{abstract}

Correspondence to: Professor Chong-Hyeon Yoon, Division of Rheumatology, Department of Internal Medicine, College of Medicine, The Catholic University of Korea, 505 Banpo 4-dong, Seoul 137-701, Republic of Korea

E-mail: chyoon@catholic.ac.kr

Professor Jong-Min Woo, Department of Psychiatry, Seoul Paik Hospital, School of Medicine, Inje University, 9 Mareunnae-ro, Seoul 100-032, Republic of Korea

E-mail: jongmin.woo@gmail.com

Abbreviations: C. obtusa, Chamaecyparis obtusa; TNF- $\alpha$, tumor necrosis factor- $\alpha$; IL-1 $\beta$, interleukin-1 $\beta$; IL-6, interleukin-6; NO, nitric oxide; COX-2, cyclooxygenase-2; iNOS, inducible nitric oxide synthase; LPS, lipopolysaccharide

Key words: Chamaecyparis obtusa, essential oil, anti-inflammatory
IL-1 $\beta$ and IL-6 levels in peritoneal fluid. In addition, EOCO reduced nitric oxide, TNF- $\alpha$ and IL- 6 production, and suppressed iNOS and COX-2 expression in LPS-stimulated RAW 264.7 cells. These results suggest that EOCO may exert anti-inflammatory effects in vivo and in vitro, and that these effects may be associated with the inhibition of inflammatory mediators. Therefore, EOCO may be considered an effective therapeutic agent for the treatment of inflammatory diseases.

\section{Introduction}

Inflammation, which is a reactive response of the body to exogenous microbes or harmful damage, is predominantly achieved by increased recruitment of immune cells to injured or infected tissues (1). Inflammation is regulated by a cascade of numerous molecular interactions and biochemical reactions, which are responsible for propagation and maturation of the inflammatory response. Various cytokines and proinflammatory mediators, including interleukin (IL)-1 $\beta$, tumor necrosis factor- $\alpha$ (TNF- $\alpha)$, IL-6, nitric oxide (NO) and prostaglandins (PGs), are involved in the inflammatory response. IL-1 $\beta$, investigated for its fever-inducing and inflammatory properties, is considered a typical proinflammatory cytokine (2). Furthermore, TNF- $\alpha$ is regarded as a central cytokine in the development of several autoimmune diseases (3). The ability to suppress IL-1 $\beta$ and TNF- $\alpha$ production in vitro and in vivo has been widely applied to screen anti-inflammatory agents (4). IL-6 is a pleiotropic cytokine that is involved in the regulation of immune responses, the acute-phase reaction of inflammation, and hematopoiesis (5). Inhibitors of these cytokines are widely used in the treatment of numerous autoimmune diseases. Cyclooxygenases (COX) are key enzymes responsible for inflammation, and the conversion of arachidonic acid to PGs and thromboxane. PGs are derived from arachidonic acid, the conversion of which is catalyzed by COX-2 (6), and are essential for generation of the inflammatory response (7). COX-2 is induced by several inflammatory stimuli, including cytokines and growth factors, whereas COX-1 is constitutively expressed in various tissues (8). In addition, inducible nitric 
oxide synthase (iNOS) sustainably produces a high output of $\mathrm{NO}$, which is an important inflammatory reaction in activated macrophages (9).

Macrophages are critical for the initiation, maintenance and resolution of the inflammatory response, including the overproduction of proinflammatory mediators, such as TNF- $\alpha$, IL-1 $\beta$, IL-6, NO and $\mathrm{PGE}_{2}$ (10). Chamaecyparis obtusa is a type of tropical tree species found in Japan and the southern regions of South Korea. Essential oil extracted from the pruned leaves and twigs of $C$. obtusa (EOCO) contains various types of monoterpenes, including $\alpha$-terpinyl acetate, $\beta$-phellandrene, $\beta$-myrcene, limonene, bornyl acetate, $\gamma$-terpinene, $\beta$-thujaplicin and $\alpha$-terpineol $(11,12)$. Although the biological activities of EOCO remain to be elucidated, antimicrobial, antifungal and anti-inflammatory effects have previously been reported $(13,14)$. EOCO has been demonstrated to reduce the production of $\mathrm{PGE}_{2}$, and the mRNA expression levels of TNF- $\alpha$ and COX-2 in LPS-stimulated peripheral blood mononuclear cells from rats (15). In addition, $\beta$-thujaplicin, an active constituent from $C$. obtusa, has been reported to decrease $\mathrm{NO}$, PGE $_{2}$, IL-6 and TNF- $\alpha$ levels, and suppress iNOS, COX2 and nuclear factor- $\kappa \mathrm{B}$ expression in LPS-stimulated RAW 264.7 cells (16). However, the anti-inflammatory effects of $C$. obtusa have yet to be confirmed in animal models of inflammation.

In the present study, the anti-inflammatory effects of EOCO were investigated on carrageenan-induced paw edema and thioglycollate-induced peritonitis mouse models. The levels of IL-1 $\beta$, IL- 6 and TNF- $\alpha$ were then detected in paw homogenates and peritoneal fluid. In addition, the inhibitory effects of EOCO were determined on the secretion of proinflammatory mediators, and the expression of iNOS and COX-2 in LPS-stimulated RAW 264.7 cells.

\section{Materials and methods}

Animals. Male C57BL/6 (B6) and ICR mice (weight, 20-30 g) were purchased from Orient Bio, Inc. (Seongnam, Korea). The mice were maintained under specific pathogen-free conditions at the Catholic Research Institute of Medical Science of the Catholic University of Korea (Seoul, Korea), and were fed standard mouse chow and water. The mice were maintained in Plexiglass cages at a constant temperature of $22 \pm 2^{\circ} \mathrm{C}$ and a relative humidity of $55 \pm 5 \%$, with a $12 \mathrm{~h}$ dark-light cycle for at least 1 week prior to the experimental session. All experimental procedures were approved by the Animal Research Ethics Committee of the Catholic University of Korea.

EOCOtreatment. EOCO used in the present study was obtained from Fosto Company (Seoul, Korea). EOCO was emulsified in dimethyl sulfoxide (DMSO; 1:1, v/v; Sigma-Aldrich, St. Louis, MO, USA) and was administered intraperitoneally (i.p.) at two different concentrations ( 5 or $10 \mathrm{mg} / \mathrm{kg}$ ) in distilled water. EOCO was administered $1 \mathrm{~h}$ prior to injection with one of the inflammation-inducing chemical agents: Carrageenan ( $n=7$ per group) or thioglycollate ( $n=6$ per group). The control mice were treated with the same volume of distilled water containing DMSO.

Carrageenan-induced paw edema model. The initial hind paw thickness of the ICR mice was determined using a pocket thickness gauge $(0-5 \mathrm{~mm})(17)$. Each group of mice received subplantar administration of $50 \mu \mathrm{l}$ carrageenan $(2 \%$ w/v; Sigma-Aldrich) in saline into the right hind paw $1 \mathrm{~h}$ following injection with EOCO or vehicle. Mice in the control group (carrageenan-negative group) were injected with an equivalent volume of saline solution at the same time-point as carrageenan was administered to the other groups. Paw thickness was measured prior to the carrageenan injection, and at 1, 2, 3, 4 and $5 \mathrm{~h}$ following carrageenan injection. The degree of swelling induced at each time-point was calculated as the difference between the initial hind paw thickness and the thickness at the respective hour following carrageenan injection.

At $5 \mathrm{~h}$, the mice were sacrificed by cervical dislocation and the skin tissues were removed from the carrageenan-injected right hind paws of each experimental group. Subsequent to rinsing in ice-cold phosphate-buffered saline (PBS), the tissue was homogenized, and the proteins were extracted from $150 \mathrm{mg}$ tissue/ml PBS containing $0.4 \mathrm{M} \mathrm{NaCl}, 0.05 \%$ Tween 20, $0.1 \mathrm{mM}$ phenylmethylsulfonyl fluoride (PMSF), $10 \mathrm{mM}$ EDTA and complete protease-inhibitor cocktail (one tablet/50 ml; Roche Diagnostics, Indianapolis, IN, USA) at $4^{\circ} \mathrm{C}$ (18). Following centrifugation twice at $12,000 \mathrm{x} \mathrm{g}$ for $15 \mathrm{~min}$ at $4^{\circ} \mathrm{C}$, the supernatant was stored at $-70^{\circ} \mathrm{C}$ for the determination of cytokine levels.

Thioglycollate-induced peritonitis model. Mice were injected intraperitoneally with 5 or $10 \mathrm{mg} / \mathrm{kg}$ EOCO, $1 \mathrm{~h}$ prior to thioglycollate injection. C57BL/6 mice were administered an i.p. injection of $2 \mathrm{ml}$ sterile $3 \%$ thioglycollate (BD Biosciences, Franklin Lakes, NJ, USA), or PBS as a control (19). After $4 \mathrm{~h}$, the mice were sacrificed by cervical dislocation, and the peritoneal cavity was flushed with $1.0 \mathrm{ml}$ Hanks' buffered salt solution without $\mathrm{Mg}^{2+}$ and $\mathrm{Ca}^{2+}$ (Welgene, Seoul, South Korea). Following centrifugation at $1,000 \times \mathrm{g}$ for $5 \mathrm{~min}$ at room temperature, the supernatant was stored at $-20^{\circ} \mathrm{C}$ for cytokine measurement by enzyme-linked immunosorbent assay (ELISA), and the pelleted peritoneal cells were collected in order to count the cell numbers. To collect more peritoneal cells, the peritoneal cavity was washed again with $10 \mathrm{ml}$ Hanks' buffered salt solution. The collected peritoneal cells from each sample were resuspended in $5 \mathrm{ml}$ Hanks' buffered salt solution, and the number of cells was determined manually with a hemocytometer using trypan blue (Gibco; Thermo Fisher Scientific, Inc.) (20).

Cell culture. The RAW 264.7 murine macrophage cell line was obtained from American Type Culture Collection (Manassas, VA, USA). The cells were cultured in RPMI-1640 (Gibco; Thermo Fisher Scientific, Inc.) supplemented with $10 \%$ heat inactivated fetal bovine serum (Wisent, Inc., St. Bruno, QC, Canada) and were maintained in a humidified $37^{\circ} \mathrm{C}$ incubator containing $5 \% \mathrm{CO}_{2}$.

Measurement of NO production. The quantity of nitrite in the culture medium was measured as an indicator of NO production. For NO quantification, RAW 264.7 cells were seeded at a density of $5 \times 10^{5}$ cells/well in 6 -well plates and were pretreated with $\operatorname{EOCO}(1,10,50$ or $100 \mu \mathrm{g} / \mathrm{ml})$ for $1 \mathrm{~h}$, followed by a $24 \mathrm{~h}$ incubation with LPS (1 $\mu \mathrm{g} / \mathrm{ml}$; Sigma-Aldrich), as 
described previously (21). Following $24 \mathrm{~h}$ of stimulation, $100 \mu 1$ of each supernatant was collected, mixed with the same volume of Griess reagent (1\% sulfanilamide and $0.1 \%$ naphthylethylenediamine dihydrochloride in $2.5 \%$ phosphoric acid), and incubated for $5 \mathrm{~min}$ at room temperature. The quantity of nitrite was determined by measuring the absorbance at a wavelength of $540 \mathrm{~nm}$ using an ELISA plate reader (Synergy ${ }^{\mathrm{TM}}$ MX, BioTek Instruments, Inc., Winooski, VT, USA). Nitrite concentration was calculated using standard solutions of sodium nitrite $\left(\mathrm{NaNO}_{2}\right)$.

Cell viability assay. RAW 264.7 cells $\left(2 \times 10^{4}\right.$ cells/well) were seeded onto 96-well flat-bottom plates and were pre-incubated for 15-18 $\mathrm{h}$. The cells were left untreated or were treated with various concentrations of $\operatorname{EOCO}(1,10,50$ or $100 \mu \mathrm{g} / \mathrm{ml})$, and were incubated at $37^{\circ} \mathrm{C}$ in a humidified atmosphere containing $5 \% \mathrm{CO}_{2}$ for $24 \mathrm{~h}$. A total of $10 \mu 1 \mathrm{MTT}(2.5 \mathrm{mg} / \mathrm{ml}$; Sigma-Aldrich) was added to each well and the cells were incubated for a further $4 \mathrm{~h}$. The MTT was then removed and the cells were lysed by the addition of $100 \mu \mathrm{l}$ DMSO to each well. The optical density was measured at a wavelength of $540 \mathrm{~nm}$ using a Synergy ${ }^{\mathrm{TM}}$ MX microplate reader.

ELISA. The expression levels of IL-1 $\beta$, TNF- $\alpha$ and IL- 6 were determined in paw homogenates, peritoneal fluid and the supernatant of lysed LPS-stimulated RAW 264.7 cells using ELISA kits (R\&D Systems, Inc., Minneapolis, MN, USA), according to the manufacturer's protocols.

Western blot analysis. The stimulated RAW 264.7 cells were washed twice with PBS and lysed in lysis buffer $[(0.5 \mathrm{M} \mathrm{NaCl}$, $20 \mathrm{mM}$ Tris- $\mathrm{HCl}, 0.25 \%$ Triton X-100, $1 \mathrm{mM}$ ethylene glycol tetraacetic acid, $1 \mathrm{mM}$ EDTA, $10 \mathrm{mM} \beta$-glycerophosphate, $10 \mathrm{mM} \mathrm{NaF}, 1 \mathrm{mM}$ benzamidine, $300 \mu \mathrm{M} \mathrm{Na}_{3} \mathrm{VO}_{4}, 2 \mu \mathrm{M}$ PMSF, $1 \mathrm{mM}$ dithiothreitol and one protease inhibitor cocktail tablet] on ice for $1 \mathrm{~h}$, followed by centrifugation at $12,000 \mathrm{x} \mathrm{g}$ for $20 \mathrm{~min}$ at $4^{\circ} \mathrm{C}$. The protein concentration of the lysates was determined using the Bradford dye-binding assay (Bio-Rad Laboratories, Inc., Hercules, CA, USA). A total of $50 \mu \mathrm{g}$ protein from the supernatants was separated by $8 \%$ sodium dodecyl sulfate-polyacrylamide gel electrophoresis, and was transferred to nitrocellulose membranes (GE Healthcare Life Sciences, Chalfont, UK) for $130 \mathrm{~min}$ at $100 \mathrm{~V}$. Subsequently, the membranes were blocked with $5 \%$ skim milk in Tris-buffered saline with Tween 20 (TBS-T; $20 \mathrm{mM}$ Tris, $500 \mathrm{mM} \mathrm{NaCl}, \mathrm{KCl}, \mathrm{pH} 7.5$, and $0.05 \%$ Tween 20) for $2 \mathrm{~h}$ at room temperature. The membranes were then agitated in blocking buffer containing rabbit anti-iNOS immunoglobulin (Ig)G (1:1,000 dilution; Santa Cruz Biotechnology, Inc., Dallas, TX, USA; cat. no. sc-8310), rabbit polyclonal anti-COX-2 (1:1,000; Cayman Chemical Company, Ann Arbor, MI, USA; cat. no. 160106) or mouse monoclonal anti- $\beta$-actin $(1: 10,000$; ABM, Inc., Richmond, BC, Canada) antibodies overnight in a cold room. Membranes were washed with TBS-T at $10 \mathrm{~min}$ intervals for $30 \mathrm{~min}$ and were then incubated with horseradish peroxidase (HRP)-conjugated goat anti-rabbit IgG (1:1,000; Santa Cruz Biotechnology, Inc.; cat. no. sc-2004) or HRP-conjugated goat anti-mouse IgG (1:10,000; Santa Cruz Biotechnology, Inc., cat. no. sc-2005) for $2 \mathrm{~h}$ at room temperature. Immunoreactive proteins were visualized using

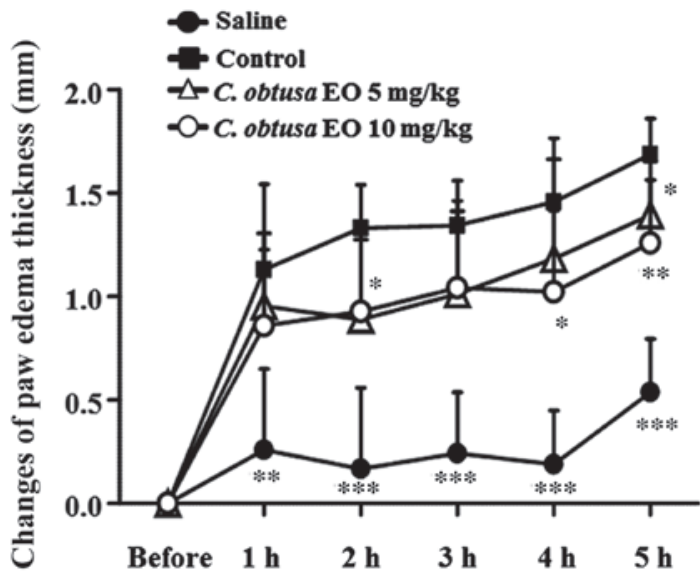

Figure 1. Effects of Chamaecyparis obtusa $\mathrm{EO}$ on carrageenan-induced mice hind paw edema. Groups of ICR mice were pretreated intraperitoneally with C. obtusa EO (5 or $10 \mathrm{mg} / \mathrm{kg}$ ) or vehicle (control) $1 \mathrm{~h}$ prior to the subplantar injection of $2 \%$ carrageenan or saline in the right hind paw. Paw thickness was measured as described in the materials and methods section. Data are presented as the mean \pm standard error of the mean ( $\mathrm{n}=7 /$ group). ${ }^{*} \mathrm{P}<0.05$, ${ }^{* *} \mathrm{P}<0.01$, and ${ }^{* * *} \mathrm{P}<0.001$ vs. the control group. $\mathrm{EO}$, essential oil.

the enhanced chemiluminescence detection system (GE Healthcare Life Sciences) on a LAS-4000 (Fujifilm, Tokyo, Japan). Densitometric values for each band were determined using ImageJ software, version 1.48 (National Institutes of Health, Bethesda, MD, USA), and were statistically analyzed.

Statistical analysis. The data are expressed as the mean \pm standard error of the mean. Comparisons between the groups were performed with Mann-Whitney U-tests. All data were analyzed using SAS 9.1 software (SAS Institute, Cary, NC, USA) and $\mathrm{P}<0.05$ was considered to indicate a statistically significant difference.

\section{Results}

Effects of EOCO on carrageenan-induced paw edema. To determine the anti-inflammatory effects of EOCO, a carrageenan-induced paw edema mouse model was used. Mice were treated with EOCO (i.p., 5 or $10 \mathrm{mg} / \mathrm{kg}$ ) or vehicle (control) $1 \mathrm{~h}$ prior to carrageenan injection, and carrageenan-induced paw thickness was measured. As presented in Fig. 1, paw thickness increased sharply $1 \mathrm{~h}$ after the subplantar injection of carrageenan, and consecutively increased until $5 \mathrm{~h}$ after the injection. Administration of $5 \mathrm{mg} / \mathrm{kg}$ EOCO (i.p.) significantly reduced paw edema 2 and $5 \mathrm{~h}$ following carrageenan injection, as compared with the control group $(\mathrm{P}<0.05)$. In addition, treatment with $10 \mathrm{mg} / \mathrm{kg}$ EOCO significantly inhibited carrageenan-induced paw edema 4 and $5 \mathrm{~h}$ following injection $(\mathrm{P}<0.05$ and $\mathrm{P}<0.01$, respectively).

To investigate the mechanism underlying the inhibitory effects of EOCO on the development of carrageenan-induced paw edema, the levels of proinflammatory cytokines in the paw tissue were determined. In the paw homogenates, the levels of IL-1 $\beta$, IL- 6 and TNF- $\alpha$ were significantly increased by carrageenan injection, as compared with saline $(\mathrm{P}<0.01$; Fig. 2). The administration of $10 \mathrm{mg} / \mathrm{kg}$ EOCO markedly inhibited the carrageenan-induced increased levels of IL-1 $\beta$ 

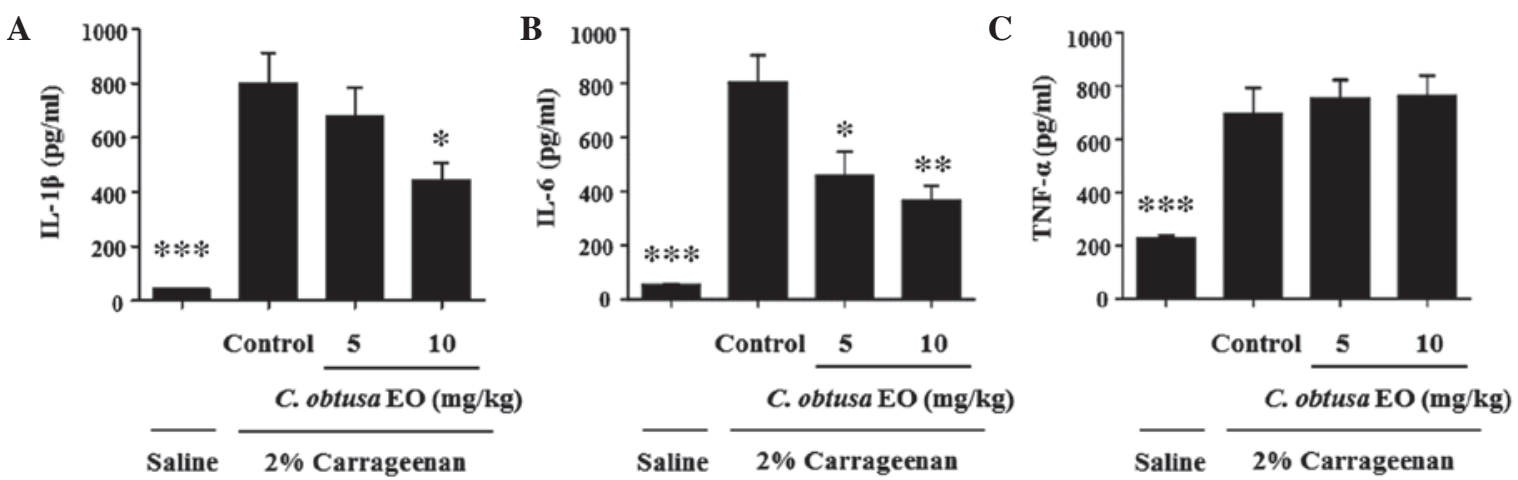

Figure 2. Effects of Chamaecyparis obtusa EO on cytokine production in the carrageenan paw edema mouse model. Groups of ICR mice were intraperitoneally pretreated with C. obtusa $\mathrm{EO}(5 \mathrm{or} 10 \mathrm{mg} / \mathrm{kg}$ ) or vehicle (control) $1 \mathrm{~h}$ prior to the subplantar injection of $2 \%$ carrageenan or saline into the right hind paw. After $5 \mathrm{~h}$, paws were homogenized and (A) IL-1 $\beta$, (B) IL- 6 and (C) TNF- $\alpha$ concentrations in the supernatant were measured by enzyme-linked immunosorbent assay. Data are presented as the mean \pm standard error of the mean ( $\mathrm{n}=7 /$ group). ${ }^{*} \mathrm{P}<0.05,{ }^{* *} \mathrm{P}<0.01$ and ${ }^{* * * *} \mathrm{P}<0.001$ vs. the control group. EO, essential oil; IL, interleukin; TNF- $\alpha$, tumor necrosis factor- $\alpha$.

A

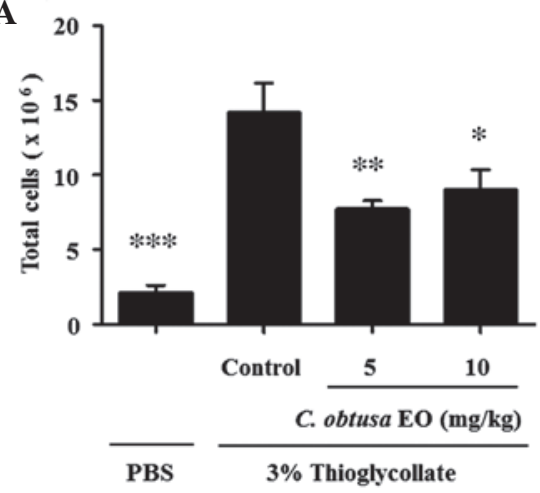

C

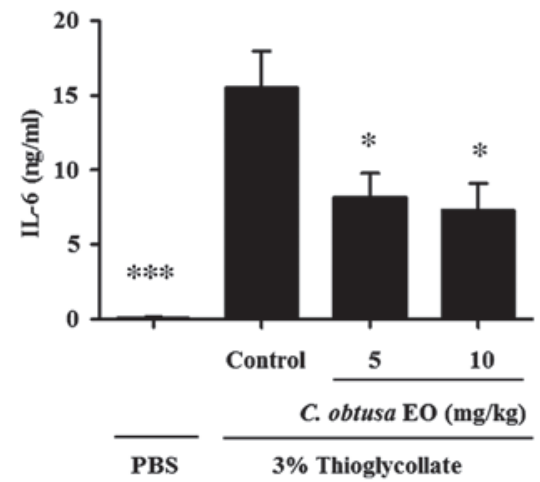

B

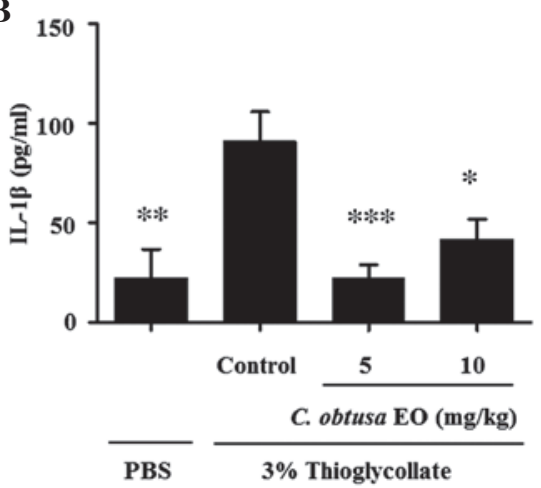

D

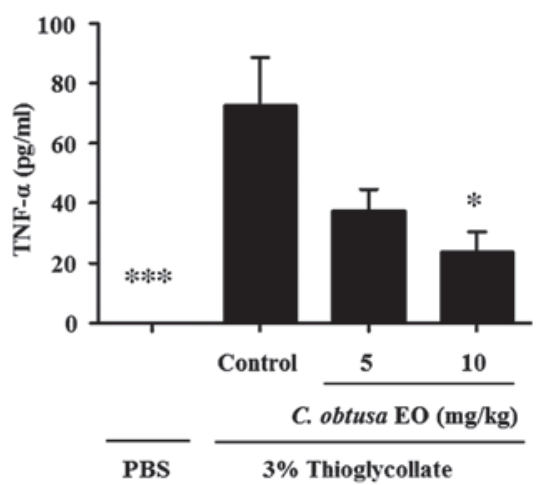

Figure 3. Effects of Chamaecyparis obtusa $\mathrm{EO}$ on the thioglycollate-induced peritonitis mouse model. Groups of C57BL/6 mice were pretreated intraperitoneally with C. obtusa EO (5 or $10 \mathrm{mg} / \mathrm{kg}$ ) or vehicle (control) $1 \mathrm{~h}$ prior to an intraperitoneal injection of $3 \%$ thioglycollate or PBS. After $4 \mathrm{~h}$, mice were sacrificed and the peritoneal fluid and cells were collected. (A) Total cells in the peritoneal fluid were counted manually with a hemocytometer. Levels of (B) IL-1 $\beta$, (C) IL-6 and (D) TNF- $\alpha$ in peritoneal fluid were determined by enzyme-linked immunosorbent assay. Data are presented as the mean \pm standard error of the mean (n=8/group). ${ }^{*} \mathrm{P}<0.05,{ }^{* * *} \mathrm{P}<0.01$ and ${ }^{* * *} \mathrm{P}<0.001$ vs. the control group. EO, essential oil; PBS, phosphate-buffered saline; IL, interleukin; TNF- $\alpha$, tumor necrosis factor- $\alpha$.

and IL-6, as compared with the control group ( $\mathrm{P}<0.05$ and $\mathrm{P}<0.01$, respectively). Conversely, $5 \mathrm{mg} / \mathrm{kg}$ EOCO significantly reduced IL-6 levels only. However, EOCO treatment did not affect the levels of TNF- $\alpha$ (Fig. 2C).

Effects of EOCO on thioglycollate-induced peritonitis. To investigate the anti-inflammatory effects of EOCO on a mouse model of peritonitis, mice were pretreated with EOCO (i.p.) $1 \mathrm{~h}$ prior to injection with $2 \mathrm{ml} 3 \%$ thioglycollate (i.p.) to induce peritonitis. After $4 \mathrm{~h}$, mice were sacrificed and the peritoneal fluid was collected. Total cells recruited into the peritoneal cavity following thioglycollate injection were markedly increased, as compared with in PBS-injected mice (Fig. 3A, $\mathrm{P}<0.01)$. Treatment with 5 or $10 \mathrm{mg} / \mathrm{kg}$ EOCO significantly reduced the number of total cells recruited into the peritoneal cavity, as compared with the control group $(\mathrm{P}<0.01$ and $\mathrm{P}<0.05$, respectively). In addition, the levels of IL-1 $\beta$, IL-6 and TNF- $\alpha$ in the peritoneal lavage fluid were significantly 

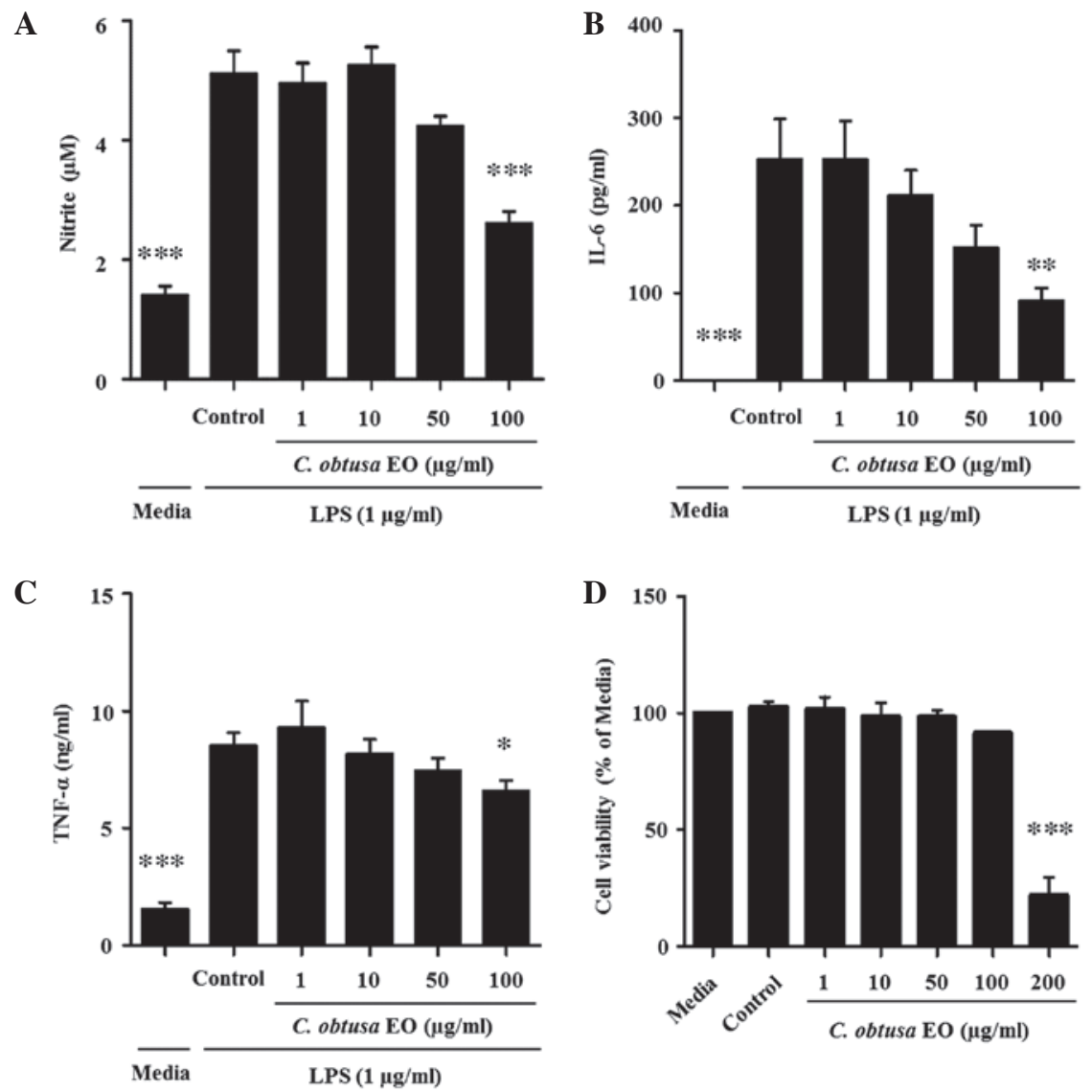

Figure 4. Effects of Chamaecyparis obtusa EO on LPS-treated RAW 264.7 macrophages cells. (A) Nitrite, (B) IL-6 and (C) TNF- $\alpha$ were measured in the supernatants of lysed bacterial LPS-induced RAW 264.7 cells. RAW 264.7 cells were pre-treated with the vehicle (control, $0.05 \%$ dimethyl sulfoxide) or 1-100 $\mu \mathrm{g} / \mathrm{ml} \mathrm{C.} \mathrm{obtusa} \mathrm{EO} \mathrm{for} 1 \mathrm{~h}$, and incubated with LPS $(1 \mu \mathrm{g} / \mathrm{ml})$ for an additional $24 \mathrm{~h}$. Nitrite and cytokine concentration in the supernatants were determined using Griess reagent and enzyme-linked immunosorbent assay, respectively. (D) RAW 264.7 cells were treated with $C$. obtusa EO (1-200 $\mu \mathrm{g} / \mathrm{ml})$ for $24 \mathrm{~h}$ and cell viability was analyzed by MTT assay. Data are presented as the mean \pm standard error of the mean ( $\mathrm{n}=9 / \mathrm{group}) .{ }^{*} \mathrm{P}<0.05,{ }^{* *} \mathrm{P}<0.01$ and ${ }^{* * * * *} \mathrm{P}<0.001$ vs. the control group. EO, essential oil; LPS, lipopolysaccharide; IL, interleukin; TNF- $\alpha$, tumor necrosis factor- $\alpha$.

A

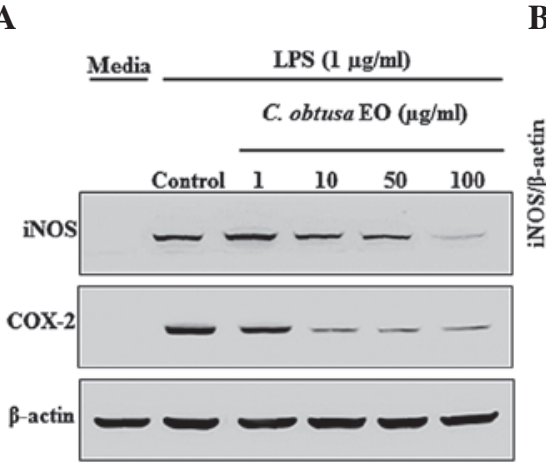

B

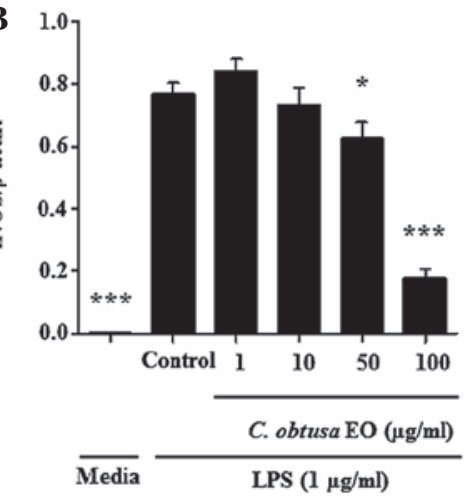

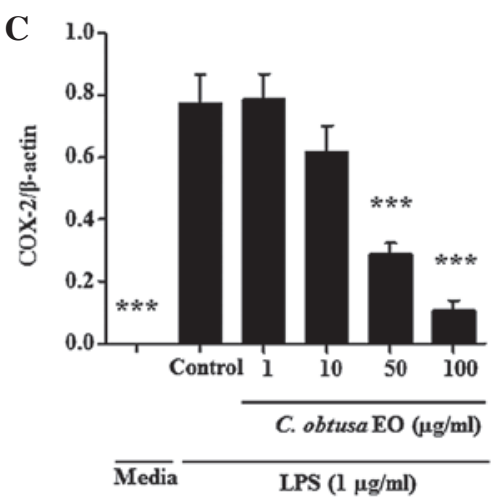

Figure 5. Effects of Chamaecyparis obtusa EO on the protein expression levels of iNOS and COX-2 in LPS-treated RAW 264.7 macrophages. (A) RAW 264.7 cells were incubated for $24 \mathrm{~h}$ with LPS $(1 \mu \mathrm{g} / \mathrm{ml})$ in the absence or presence of $C$. obtusa EO (1, 10,50 or $100 \mu \mathrm{g} / \mathrm{ml})$. C. obtusa EO was added $1 \mathrm{~h}$ prior to stimulation with LPS. Lysed cells were then prepared and subjected to western blotting using antibodies specific for iNOS and COX-2. $\beta$-actin served as an internal control. Protein expression levels of (B) iNOS and (C) COX-2 were determined following analysis of the blots. Data are presented as the mean \pm standard error of the mean ( $\mathrm{n}=9$ /group). $\mathrm{P}<0.05$ and ${ }^{* * *} \mathrm{P}<0.001$ vs. the control group. EO, essential oil; LPS, lipopolysaccharide; COX-2, cyclooxygenase-2; iNOS, inducible nitric oxide synthase.

reduced by EOCO treatment, as compared with the control group (Fig. 3B-D; P<0.05).

Effects of EOCO on LPS-stimulated RAW 264.7 cells. To investigate whether the anti-inflammatory effects of EOCO in thioglycollate-induced peritonitis were due to the inhibition of macrophage function, LPS-stimulated RAW 264.7 murine macrophage cells were treated with EOCO. RAW 264.7 cells were cultured with LPS $(1 \mu \mathrm{g} / \mathrm{ml})$ in the presence or absence of $\operatorname{EOCO}(1,10,50$ and $100 \mu \mathrm{g} / \mathrm{ml})$. 
EOCO decreased the production of NO, IL- 6 and TNF- $\alpha$ by LPS-stimulated RAW 264.7 cells in a dose-dependent manner, and the inhibition was statistically significant at a dose of $100 \mu \mathrm{g} / \mathrm{ml}(\mathrm{P}<0.001, \mathrm{P}<0.01$ and $\mathrm{P}<0.05$, respectively; Fig. 4A-C). The cytotoxicity of EOCO on RAW 264.7 cells was determined using the MTT assay. Cells cultured in the presence of EOCO $(1-100 \mu \mathrm{g} / \mathrm{ml})$ for $24 \mathrm{~h}$ demonstrated no change in viability, as compared with those incubated in culture media only. However, cell viability was significantly decreased by $\sim 78.8 \%$ following treatment with $200 \mu \mathrm{g} / \mathrm{ml}$ EOCO (Fig. 4D).

In order to investigate whether the inhibition of $\mathrm{NO}$ production was due to decreased iNOS and COX-2 protein expression, the effects of EOCO on iNOS and COX-2 protein expression levels were analyzed by western blotting. As presented in Fig. 5, the protein expression levels of iNOS and COX-2 in RAW 264.7 cells were significantly increased by LPS. The LPS-stimulated expression levels of iNOS and COX-2 proteins were significantly inhibited by treatment with 50 and $100 \mu \mathrm{g} / \mathrm{ml}$ of EOCO (Fig. 5).

\section{Discussion}

The results of the present study demonstrated the anti-inflammatory effects of EOCO in vivo and in vitro. Administration of EOCO significantly suppressed carrageenan-induced paw edema, and the production of IL- $1 \beta$ and IL- 6 in the paws. In the thioglycollate-induced peritonitis model, the number of total cells, and the levels of IL-1 $\beta$, IL- 6 and TNF- $\alpha$ were significantly reduced in the peritoneal fluid. Carrageenan-induced paw inflammation is a commonly used model for the investigation of novel anti-inflammatory agents (22). The development of paw edema in mice following injection with the phlogistic agent is hypothesized to be a biphasic mechanism, of which the first $1-2 \mathrm{~h}$ is due to the release of histamine or serotonin, and the second phase of edema formation is due to the release of PGs/protease and lysosome, which peaks at $3 \mathrm{~h}$ (22). Local release of proinflammatory cytokines, including TNF- $\alpha$, IFN- $\gamma$ and IL-1 $\beta$, is also induced by carrageenan injection (23). In the present study, EOCO exhibited significant inhibitory effects $2 \mathrm{~h}$ after carrageenan treatment, which continued to $5 \mathrm{~h}$. These results suggested that the underlying mechanism of action of EOCO may involve blocking PG synthesis and/or proinflammatory cytokine release.

Murine thioglycollate-induced peritonitis is an appropriate model with which to study inflammatory events, which are accompanied by inflammatory mediator production and leukocyte accumulation. In this model, neutrophil numbers start to increase and reach peak levels between 4 and $24 \mathrm{~h}$ after treatment, whereas macrophage numbers start to increase at $24 \mathrm{~h}$ and reach peak levels at 3 to 4 days (24). In addition to leukocyte recruitment, another primary response to inflammation is the secretion of proinflammatory cytokines, such as IL- $1 \beta$, IL- 6 and TNF- $\alpha$, by resident or recruited macrophages. The results of the present study suggested that administration of EOCO may alleviate thioglycollate-induced peritonitis by inhibiting the function of intraperitoneal macrophages.

The present study also detected the effects of EOCO on macrophages. Treatment with EOCO inhibited the production of NO, IL-6 and TNF- $\alpha$ in LPS-stimulated RAW 264.7 cells.
In addition, the expression levels of iNOS and COX-2 were suppressed by EOCO treatment.

In conclusion, the results of the present study demonstrated that EOCO may exert anti-inflammatory effects in animal models via its ability to decrease the production of proinflammatory mediators and cytokines. These data suggest that EOCO may be therapeutically useful for the treatment of inflammatory diseases.

\section{Acknowledgements}

The present study was conducted with the support of Forest Science \& Technology Projects (project no. S111114L020100) provided by Korea Forest Service.

\section{References}

1. Pomin VH: Sulfated glycans in inflammation. Eur J Med Chem 92: 353-369, 2015.

2. Luger TA, Stadler BM, Luger BM, Mathieson BJ, Mage M, Schmidt JA and Oppenheim JJ: Murine epidermal cell-derived thymocyte-activating factor resembles murine interleukin 1. J Immunol 128: 2147-2152, 1982.

3. Keffer J, Probert L, Cazlaris H, Georgopoulos S, Kaslaris E, Kioussis D and Kollias G: Transgenic mice expressing human tumour necrosis factor: A predictive genetic model of arthritis. EMBO J 10: 4025-4031, 1991.

4. Dinarello CA: Anti-inflammatory agents: Present and future. Cell 140: 935-950, 2010.

5. Tilg H, Trehu E, Atkins MB, Dinarello CA and Mier JW: Interleukin-6 (IL-6) as an anti-inflammatory cytokine: Induction of circulating IL-1 receptor antagonist and soluble tumor necrosis factor receptor p55. Blood 83: 113-118, 1994.

6. Vane JR, Bakhle YS and Botting RM: Cyclooxygenases 1 and 2. Annu Rev Pharmacol Toxicol 38: 97-120, 1998.

7. Ricciotti E and FitzGerald GA: Prostaglandins and inflammation. Arterioscler Thromb Vasc Biol 31: 986-1000, 2011.

8. Kim HS, Kim T, Kim MK, Suh DH, Chung HH and Song YS: Cyclooxygenase-1 and -2: Molecular targets for cervical neoplasia. J Cancer Prev 18: 123-134, 2013.

9. Pokharel YR, Liu QH, Oh JW, Woo ER and Kang KW: 4-Hydroxykobusin inhibits the induction of nitric oxide synthase by inhibiting NF-kappaB and AP-1 activation. Biol Pharm Bull 30: 1097-1101, 2007.

10. Mosser DM and Edwards JP: Exploring the full spectrum of macrophage activation. Nat Rev Immunol 8: 958-969,2008.

11. Bae D, Seol H, Yoon HG, Na JR, Oh K, Choi CY, Lee DW, Jun W, Youl Lee K, Lee J, et al: Inhaled essential oil from Chamaecyparis obtuse ameliorates the impairments of cognitive function induced by injection of $\beta$-amyloid in rats. Pharm Biol 50: 900-910, 2012.

12. JooSS, Yoo YM,Ko SH,Choi W,Park MJ,Kang HY,Choi KC,Choi IG and Jeung EB: Effects of essential oil from Chamaecypris obtusa on the development of atopic dermatitis-like skin lesions and the suppression of Th cytokines. J Dermatol Sci 60: 122-125, 2010.

13. Hong EJ, Na KJ, Choi IG, Choi KC and Jeung EB: Antibacterial and antifungal effects of essential oils from coniferous trees. Biol Pharm Bull 27: 863-866, 2004.

14. Li Q, Kobayashi M, Wakayama Y, Inagaki H, Katsumata M, Hirata Y, Hirata K, Shimizu T, Kawada T, Park BJ, et al: Effect of phytoncide from trees on human natural killer cell function. Int J Immunopathol Pharmacol 22: 951-959,2009.

15. An BS, Kang JH, Yang H, Jung EM, Kang HS, Choi IG, Park MJ and Jeung EB: Anti-inflammatory effects of essential oils from Chamaecyparis obtusa via the cyclooxygenase-2 pathway in rats. Mol Med Rep 8: 255-259, 2013.

16. Shih MF, Chen LY, Tsai PJ and Cherng JY: In vitro and in vivo therapeutics of $\beta$-thujaplicin on LPS-induced inflammation in macrophages and septic shock in mice. Int J Immunopathol Pharmacol 25: 39-48, 2012.

17. Paul S, Shin HS and Kang SC: Inhibition of inflammations and macrophage activation by ginsenoside-Re isolated from Korean ginseng (Panax ginseng C.A. Meyer). Food Chem Toxicol 50: 1354-1361, 2012. 
18. de Lima FO, Alves V, Barbosa Filho JM, Almeida JR, Rodrigues LC, Soares MB and Villarreal CF: Antinociceptive effect of lupeol: Evidence for a role of cytokines inhibition. Phytother Res 27: 1557-1563, 2013.

19. Call DR, Nemzek JA, Ebong SJ, Bolgos GL, Newcomb DE and Remick DG: Ratio of local to systemic chemokine concentrations regulates neutrophil recruitment. Am J Pathol 158: 715-721, 2001.

20. Louis KS and Siegel AC: Cell viability analysis using trypan blue: Manual and automated methods. Methods Mol Biol 740: 7-12, 2011.

21. Huang GJ, Huang SS and Deng JS: Anti-inflammatory activities of inotilone from Phellinus linteus through the inhibition of MMP-9, NF- $\kappa$ B, and MAPK activation in vitro and in vivo. PLoS One 7: e35922, 2012.
22. Posadas I, Bucci M, Roviezzo F, Rossi A, Parente L, Sautebin L and Cirino G: Carrageenan-induced mouse paw oedema is biphasic, age-weight dependent and displays differential nitric oxide cyclooxygenase-2 expression. Br J Pharmacol 142: 331-338, 2004.

23. Wang JP, Zhou YM, Ye YJ, Shang XM, Cai YL, Xiong CM, Wu YX and Xu HX: Topical anti-inflammatory and analgesic activity of kirenol isolated from Siegesbeckia orientalis. J Ethnopharmacol 137: 1089-1094, 2011.

24. Lam D, Harris D and Qin Z: Inflammatory mediator profiling reveals immune properties of chemotactic gradients and macrophage mediator production inhibition during thioglycollate elicited peritoneal inflammation. Mediators Inflamm 2013 931562, 2013. 